\title{
MULTIPLE SCLEROSIS ASSOCIATED WITH ANAEMIC SYNDROME: A RETROSPECTIVE ANALYSIS AND LITERATURE REVIEW
}

\author{
Nadezhda S. Deleva, Alexandra J. Tzoukeva, Ara G. Kaprelyan, Kalina V. Drenska \\ Department of Neurology, Medical University - Varna
}

\begin{abstract}
:
An association of MS with different anaemic syndromes, most often pernicious and Vit. B12 deficiency anaemia has been reported in the literature. Accordingly, the coincidence of anaemia with MS has been considered to impact seriously on clinical presentation, therapeutic strategy and patient's quality of life.

Objective: To perform a retrospective analysis of 18 cases with anaemic syndrome as a factor of comorbidity in patients with MS.

Material and methods: 18 MS patients (15 women and 3 men) with RRMS (13), PPMS (2), and SPMS (3) diagnosed according to McDonald criteria were included in the present study. Average age was $36.4 \pm 8.5(22-42)$ years, average disease duration 10.6 \pm 6.8 (4-18) years and means EDSS $3.5 \pm 2.5$ points (2-6). All individuals underwent clinical, MRI and hematological examinations.

Results: The study group included patients with pernicious $(n=8)$, Vitamin B12 $(n=6)$, and iron $(n=3)$ deficiency anaemia, as well as with $\beta$-thalassemia $(n=1)$. In 12 patients anaemic syndrome proceeded MS and in 6 evolved during the course of the desease.

Conclusion: Our own notices and literature review suggests a possible causative relation between MS and anaemic syndrome. The role of this coincidence on clinical presentation, necessity of additional treatment, and patient's quality of life is discussed.
\end{abstract}

Key words: MS, vitamin B 12 deficiency, pernicious anaemia, iron deficiency anaemia

An association of MS with different anaemic syndromes has been reported $(1,3,5,8,10,12)$. Most common are states of B12 deficiency and pernicious anaemia, occurring before or during the development of MS $(2,13)$. The aetiology of vitamin B12 deficiency in MS remains not always specified, but it is assumed that disorders are possible, both in absorption or in the transport of vitamin B12. Despite the unexplained nature of the association of vitamin B12 deficiency and MS, a similarity of the pathogenetic mechanisms is assumed. In addition to the well known role of vitamin B12 as a cofactor in the formation of myelin, the significant immunomodulatory and neurotrophic effects are discussed (9). On the other hand, the epidemiological picture of pernicious anaemia shows significant similarity to that of MS $(4,11)$. Accordingly, the coincidence of anaemia with MS has been considered to impact seriously on clinical presentation, therapeutic strategy and patient's quality of life. Special attention is paid to the transposition of symptoms of the anaemic syndrome to the classical clinical picture in MS $(6,7)$.

\section{AIM AND METHODS:}

The aim of this study was to perform a retrospective analysis of 18 cases with anaemic syndrome as a comorbid factor in MS patients hospitalized in First Department of Neurology, Varna University Hospital. All patients underwent a neurological, neuro-ophthalmological and hematological examinations, MRI, vitamin B12, and serum iron assessment.

\section{RESULTS:}

All 18 patients were females, aged 22 to 42 years (36.4 \pm 8.5$)$ with clinically definitive MS, according to the criteria of McDonald, with a disease duration of 4 to 18 years (10.6 \pm 6.8 ), and EDSS - from 2.0 to $6(3.5 \pm 2.5)$.

Thirteen of them were with relapsing-remitting form, 2 - with primary progressive and 3 - with secondary progressive (fig.1). Associated with anaemic syndromes were: 8 patients - with pernicious anaemia, 3 patients with iron deficiency anaemia, 6 patients - with B 12 deficiency without anaemia, and 1 patient - with вthalassemia heterozygous form (fig. 2). In 13 (72.2\%) patients anaemia occurs before the age of 40; in 12 - prior to the start of MS, others are diagnosed in the course of the neurological disease. In all patients a specific treatment of anaemia was conducted.

\section{CONCLUSION AND DISCUSSION:}

The described cases similar to the literature review suggest a possible causative relation between MS and anaemic syndrome $(1,5,6,7,10)$. The analysis could be useful for clarifying the nature of comorbidity of these diseases. Given the data in publications on prevalence of 
vitamin B 12 deficiency or pernicious anaemia among hematological syndromes in patients with MS, confirmed also in our study, the monitoring of vitamin B 12 levels is of clinical interest $(2,4,9,11,13)$. In case of abnormal blood count, it is necessary to take into account the role of the anaemic syndrome on the comprehensive assessment of quality of life, having in mind the transposition of symptoms to the known clinical picture of $\operatorname{MS}(3,8,12)$. The discussion of the individual or additional administration of vitamin $\mathrm{B}$ 12 in the treatment plan for patients is of a great importance.

Figure 1. Distribution of MS patients by forms

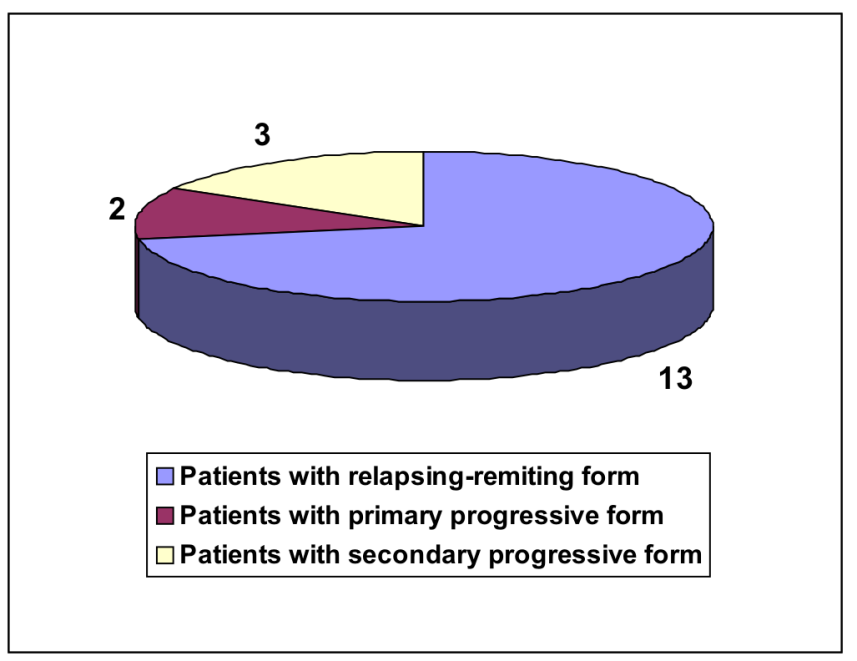

Figure 2. Assocition of MS patients with anemic sindromes

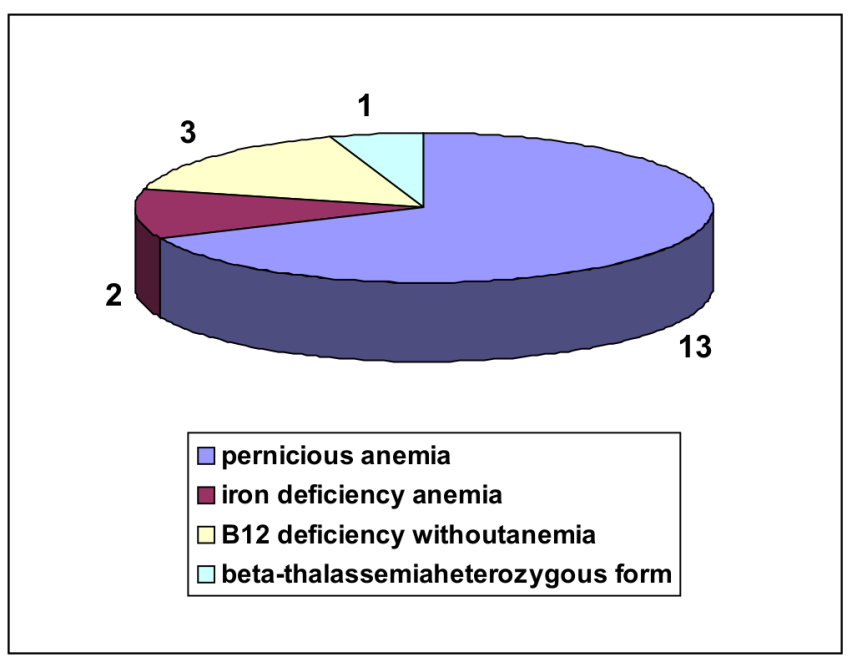

\section{REFERENCES:}

1. Alanoglu G, Kilbas S, Arslan C, Senol A, Kultuhan S. Autoimmune hemolytic anemia during interferon-beta-I $\mathrm{b}$ treatment for multiple sclerosis. Mult Scler. 2007 Jun;13(5):683-5. Epub 2007 Mar 15. [PubMed]

2. Najim al-Din AS, Khojali M., Habbosh H., Farah S., Idris AR, AlMuhtasib F. Macrocytosis in multiple sclerosis. A study in 82 de novo Arab patients. J Neurol Neurosurg Psychiatry. 1991 May;54:415-416. [PubMed] [CrossRef]

3. Belniak E., Stelmasiak Z., Рариж E. Multiple sclerosis and other autoimmune diseases. Neurol Neurochir Pol. 2007
May-Jun;41(3):259-266. (Article in Polish) [PubMed]

4. Gruener D., Kunkel E., Snyderman D., Infante M., Rodgers C., Field H. Dietary vitamin B12 deficiency in a patient with multiple sclerosis. Gen Hosp Psychiatry. 1994 May;16(3):224-228. [PubMed]

5. Hinterberger-Fischer M., Kier P., Forstinger I., Lechner K., Kornek G., Breyer S., et al. Coincidence of severe aplastic anaemia with multiple sclerosis or thyroid disorders. Report of 5 cases. Acta haematologica.1994; 93(3):136-139. [PubMed]

6. Kang J., Chen Y., Lin H.
Comorbidities amongst patients with multiple sclerosis: a population-based controlled study. Eur J Neurol. 2010 Sep;17(9):1215-1219. Epub 2010 Feb 23. [PubMed] [CrossRef]

7. Marrie R., Horwitz R. Emerging effects of comorbidities on multiple sclerosis. Lancet Neurol. 2010 Aug;9(8):820-828. [PubMed] [CrossRef]

8. Marrie R., Horwitz R., Cutter G, Tyry T, Vollmer T. Association between comorbidity and clinical characteristics of MS. Acta Neurol Scand. 2011 Aug;124(2):135-141. Epub 2010 Sep 29. [PubMed] [CrossRef]

9. Miller A, Korem M, Almog R, 
Galboiz Y. Vitamin B12, demyelination, remyelination and repair in multiple sclerosis. J Neurol Sci. 2005 Jun 15;233(12):93-97. [PubMed] [CrossRef]

10. Ramsaransing G., Fokkema M., Teelken A., Arutjunyan A., Koch M., De Keyser J. Plasma homocysteine levels in multiple sclerosis. J Neurol Neurosurg Psychiatry. 2006 Feb;77(2):189-192.
[PubMed] [CrossRef]

11. Reynolds E. Multiple sclerosis and vitamin B12 metabolism. J Neuroimmunol. 1992 Oct;40(2-3):225-230. [PubMed]

12. Sцderberg KC, Jonsson F., Winqvist O., Hagmar L., Feychting M. Autoimmune diseases, asthma and risk of haematological malignancies: a nationwide case-control study in Sweden. Eur $J$
Cancer. 2006 Nov;42(17):3028-3033. Epub 2006 Sep 1. [PubMed] [CrossRef]

13. Triantafyllou N., Evangelopoulos ME, Kimiskidis VK, Kararizou E., Boufidou F., Fountoulakis KN, et al. Increased plasma homocysteine levels in patients with multiple sclerosis and depression. Ann Gen Psychiatry. 2008 Sep 9;7:17 [PubMed] \{CrossRef]

Address for correspondence:

Prof. Nadezhda Deleva

Department of Neurology

Prof. Paraskev Stoyanov Medical University of Varna,

55, M. Drinov str., 9002 Varna, Bulgaria

E-mail: n_deleva@yahoo.com 